\title{
ÉRTELMEZÉSI HÉZAGOK AZ EUROCODE 3 SZABVÁNY ELŐÍRÁSAINAK ALKALMAZÁSA SORÁN
}

\section{THE MISSING HOLISTIC APPROACH IN DESIGN APPLICATION OF EUROCODE 3}

\author{
Sánduly Annabella, ${ }^{1}$ Tóth Anett, ${ }^{2}$ Lőrincz Barnabás-Attila ${ }^{3}$ \\ Kolozsvári Müszaki Egyetem, Építőméröki kar; Gordias Kft., Kolozsvár, Románia \\ ${ }^{1}$ annabella.sanduly@gordias.ro \\ ${ }^{2}$ anett.toth@gordias.ro \\ ${ }^{3}$ barnabas.lorincz@gordias.ro
}

\begin{abstract}
The Steel Eurocodes have an important role in the correct and adequate design of steel structures. Most of the programs, which are used for the static analysis of these structures, take into consideration the information offered by the Eurocodes, thus giving the opportunity to entrust them with the task to solve those problems, which are not clear and easily understandable for the user. As it will be proven in this article, the Eurocode 3 in some cases does not offer proper, clear explanations regarding some decisions. The main critics for the whole Eurocode package is that the user might not see clearly the connection between the scattered parts of the final solution.
\end{abstract}

Keywords: Eurocode 3, steel structures, cold formed steel shapes, interpretation.

\section{Összefoglalás}

Az acélszerkezetekre vonatkozó Európai szabványok jelentős szerepet töltenek be a tartószerkezetek helyes és tudatos tervezése során. A statikai tervező programok nagy része már ezen szabványok előírásainak figyelembevételével dolgozik, és ennek tudatában „rábízzuk” az általunk megkérdőjelezhető, néhol csak zavarosan értelmezhető problémák megoldásait. A jelen dokumentumban példaként szolgál az Eurocode 3 szabvány, amely néhány lényeges döntésben nem kínál egyértelmű útmutatást, valamint amelyben a felhasználó számára nehezen kapcsolhatók össze a részletekben megoldott problémák.

Kulcsszavak: Eurocode 3, acélszerkezetek, hidegen hajlított szelvények, értelmezés.

\section{Bevezetés}

Az építmények tervezése kézi számítási módszerekkel a 21. században merészségnek számít, hiszen a szoros határidők sokasága rákényszeríti a tervezőt a leggyorsabb eljárás alkalmazására, amely a statikai tervező programok használatát jelenti. Az egyetemi oktatásból újonnan kikerült, tapasztalatlan mérnökként tudjuk-e értelmezni a szoftver által szolgáltatott eredményeket, hogy mi is történik a háttérben, abban a bizonyos „fekete dobozban”, hogy milyen módszer szerinti számoláson halad végig, mennyi olyan kérdésben „dönt” a program, amely előtt értetlenül állnánk és több órányi kutatómunkát áldoznánk rá, ha a kézi számolás módszerét választanánk? Milyen akadályok gördülnek elénk, ha megpróbálkozunk egy acélcsarnok alapos ellenőrzésével az Eurocode 3 szabvány előírásait követve? Ezeknek a kérdéseknek a megválaszolása érdekében létrehozott 3D szerkezet az 1. ábrán látható.

\section{Szerkezet leírása}

A keresztirányú keretek hidegen hajlított, vékonyfalú C szerkezeti idomokból vannak kialakít- 


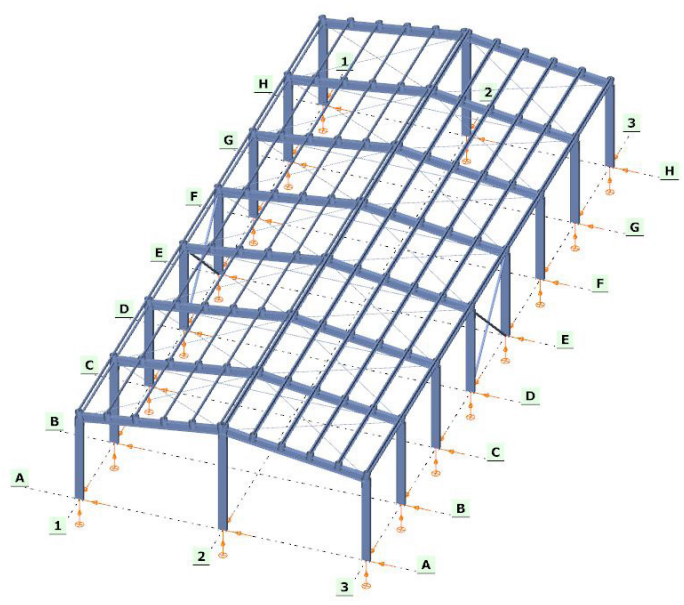

1. ábra. $3 D$ szerkezet

va. Geometriailag 12 m-es fesztávolsággal, 4 m-es keretkiosztással és 4 m-es vállmagassággal rendelkezik [1].

A vékonyfalú, hidegen hajlított szelvényeket (2. ábra) 4. osztályú keresztmetszetként kezeltük, ilyenformán megnövelve a szerkezetünkre vonatkozó előírások számát, hiszen többek között figyelembe kellett venni a lemezhorpadás hatását is. Ebben az esetben elsősorban az Eurocode 3 szabvány első [2] és harmadik [3] részének irányelveit szükséges követni.

A keret (3. ábra) kiválasztása, a szerkezet ellenőrzésének folyamatához az igénybevételek nagyságától függ.

A keresztmetszetek ellenállásának vizsgálata viszonylag gördülékenyen végigvezethető az Eurocode 3 szabvány szerint, hiszen a keresztmetszeti tulajdonságok számbeli meghatározását megtalálhatjuk a szelvénynek megfelelő - a gyártó által kiadott - termékkatalógusban.

\section{Stabilitásvesztés ellenőrzésének fo- lyamata az Eurocode 3 szabvány szerint}

Az Eurocode 3 szabvány első részének a szerkezeti rudak stabilitási ellenállására vonatkozó fejezetein végighaladva, egy, a stabilitásvesztés ellenőrzésének a folyamatáról alkotott, átfogó, integrált kép kialakulására számítunk, viszont a mozaikdarabkák nem mindig kapcsolódnak öszsze.

A globális, rugalmas analízis során az Eurocode 3 szabvány a csökkentő tényezős módszer szerinti számoláson vezet végig, amelynek két eljárása használható: az egyenértékű szerkezeti elem módszere és az általános módszer. Az általános metódus alkalmazásához végeselem módszeren alapuló metodológia tanácsos.

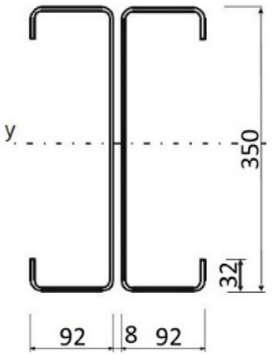

a)

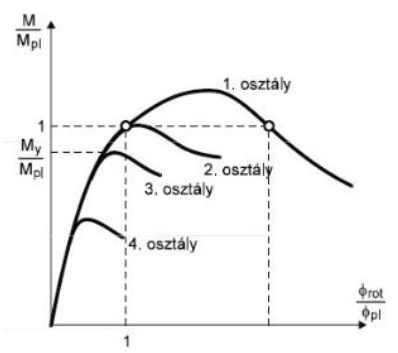

b)
2. ábra. a) 2C350/3 szelvény;

b) Nyomaték-elfordulás görbék [4]

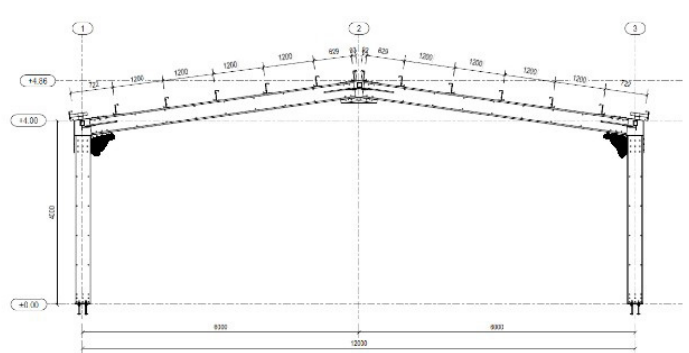

3.ábra. Vékonyfalú, hidegen alakított idomokból alkotott keret

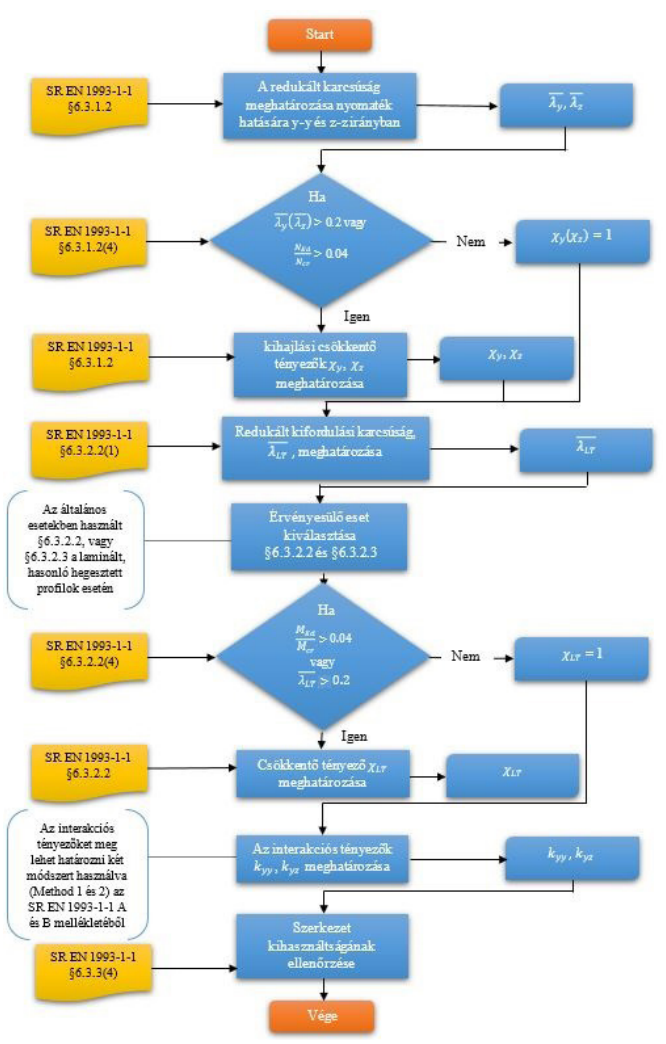

4. ábra. Stabilitásvesztés számolásának folyamata 
Az egyenértékű szerkezeti elem módszere feltételezi a valós szerkezet helyettesítését egyszerü szerkezeti elemmel, amely megköveteli az egyenértékű szerkezeti elem kihajlási hosszaként használt azon értékét, amely visszaadja a tényleges szerkezet stabilitásvizsgálatának eredményit. Egyszerübben kifejezve a módszer helyessége a kihajlási hossz megfelelő meghatározásán áll, vagy bukik. Az Eurocode 3 szabvány épületekre vonatkozó részeiben nem található a kihajlási hosszra vonatkozó egyértelmű előírás sem és az Eurocode más részeire való hivatkozás sem. Ennek hiányát, téves értelmezésből adódóan, helytelen értékek használata kísérheti.

\section{Rövid esettanulmány}

A 3. ábrán látható vékonyfalú, hidegen alakított profilokból alkotott keret oszlopának a vizsgálata során, a kihajlási hossz különböző értékei nagyban befolyásolják a szerkezet kihasználtságát.

Ezt hivatottak szemléltetni az alábbi egyszerű számolások az Eurocode 3 szabvány alapján. Feltételezzük, hogy az oszlop NEd=500 kN mértékü tiszta nyomóerőnek van kitéve.

A kihajlási ellenállást az Eurocode 3 szabvány első részének a 6.3 fejezetében [2] megtalálható képlettel számoljuk:

$$
N_{b, R d}=\frac{\chi \cdot A_{e f f} \cdot f_{y}}{\gamma_{M 1}}
$$

A kihajlási hossz fele az oszlop magasságának $\left(L_{\text {eff }}=L_{o}=2000 \mathrm{~mm}\right)$ a keretsíkban és arra merőlegesen is:

$$
\begin{aligned}
& L_{e f f, y}=0.5 \cdot L_{o}=2000 \mathrm{~mm} \\
& L_{e f f, z}=0.5 \cdot L_{o}=2000 \mathrm{~mm} \\
& N_{E d} / N_{b, R d, y} \cdot 100=77.51 \% \\
& N_{E d} / N_{b, R d, z} \cdot 100=87.99 \%
\end{aligned}
$$

A kihajlási hossz oszlop magasságának a 70\%-a $\left(L_{e f f}=L_{o}=2800 \mathrm{~mm}\right)$ a keretsíkban és arra merőlegesen is:

$$
\begin{aligned}
& L_{e f f, y}=0.7 \cdot L_{o}=2800 \mathrm{~mm} \\
& L_{e f f, z}=0.7 \cdot L_{o}=2800 \mathrm{~mm} \\
& N_{E d} / N_{b, R d, y} \cdot 100=78.50 \% \\
& N_{E d} / N_{b, R d, z} \cdot 100=98.52 \%
\end{aligned}
$$

A kihajlási hossz egyenlő az oszlop magasságá$\operatorname{val}\left(L_{e f f}=L_{o}=4000 \mathrm{~mm}\right)$ a keretsíkban és arra merőlegesen is:

$$
L_{e f f y}=L_{o}=4000 \mathrm{~mm}
$$

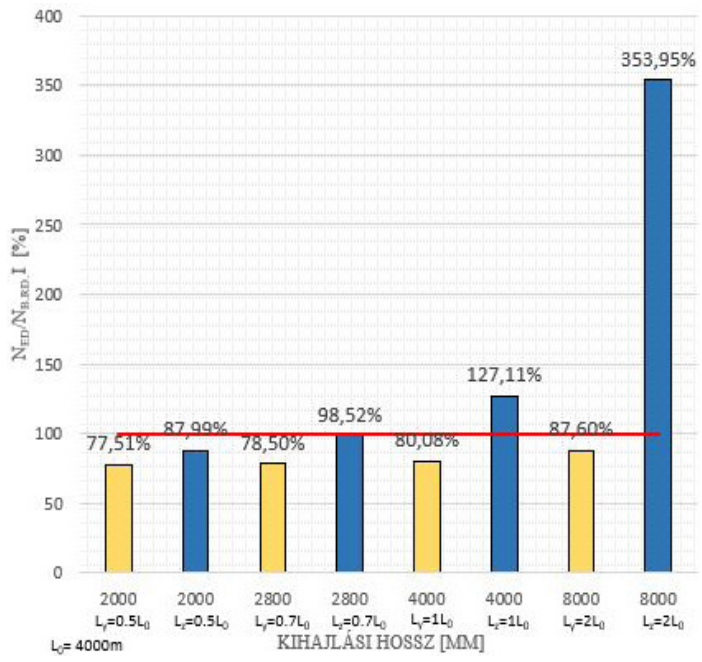

5. ábra. Különböző kihajlási hosszak befolyása az elem kihasználtságára

$L_{e f f, z}=L_{o}=4000 \mathrm{~mm}$

$N_{E d} / N_{b, R d, y} \cdot 100=80.08 \%$

$N_{E d} N_{b, R d, z} \cdot 100=127.11 \%$

A kihajlási hossz kétszerese az oszlop magasságával a keretsíkra merőlegesen és a keret síkjában is $\left(L_{e f f}=L_{o}=8000 \mathrm{~mm}\right)$

$$
\begin{aligned}
& L_{e f f, y}=L_{o}=8000 \mathrm{~mm} \\
& L_{e f f, z}=L_{o}=80 \mathrm{~mm} \\
& N_{E d} / N_{b, R d, y} \cdot 100=87.60 \% \\
& N_{E d} / N_{b, R d, z} \cdot 100=353.95 \%
\end{aligned}
$$

Abban az esetben, amikor a kihajlás a keretsíkban történik a megfigyelhető különbség 11-12\% között van, viszont a keret síkjára merőleges kihajlásra vonatkozó eredmények közötti legnagyobb különbség 30-31\% körüli. Ez azt jelenti, hogy a kihajlási hossznak téves értelmezése során megtörténhet, hogy az oszlop stabilitásvesztése az Eurocode által javasolt határon belüli értéket eredményez, de valójában nagy mértékben túllépi ezt a határt.

\section{Interakciós tényezők számolása két módszerrel}

Amennyiben a kihajlás és kifordulás interakciója következtében fellépő stabilitásvesztés ellenőrzését végezzük, szükséges meghatározni a kritikus nyomaték értékét, viszont a számolására vonatkozó javaslat nem található az Eurocode 3 szabványban. Ennek a képleteken keresztül törté- 
nő értelmezése az Eurocode 9 szabvány I függelékében található.

A kritikus nyomaték számolása mellett nehézséget jelenthet az interakciós tényezők meghatározása is, amelyre az Eurocode 3 két, első ránézésre nagyon hasonló módszert javasol. Ahogy a Papp Ferenc, Ph.D: Szerkezetépítés II. című tervezési segédletben [5] is olvasható, az első „Method 1”, a „francia-belga” munkacsoport módszere, amely folyamatos átmenetet ad a keresztmetszeti és stabilitási ellenállások között, míg a „német-osztrák” munkacsoport módszere a „Method 2” egyszerűbb, érthetőbb képleteket bocsát a rendelkezésünkre, az ellenállások közötti kapcsolat kevésbé van kidolgozva.

Az interakciós tényezők értékei a két metódus szerinti számolás során a következő eredményekhez vezettek:

A „Method 1” számítási folyamat $\mathrm{k}_{\mathrm{yy}}=0,95$ értéket eredményezi, ami a „Method 2"-vel szemben figyelembe veszi a kritikus erőket különböző kihajlási formák esetében.

A „Method 2” alapján végzett számítás során az interakciós tényező értéke a következő: $\mathrm{k}_{\mathrm{yy}}=0,62$.

A két módszer eredményei között a különbség 34-35\%.

\section{Következtetések}

A szerkezet viselkedésének alapos vizsgálatához felhasznált szakirodalom száma, esetünkben meghaladta húsz-harminc különböző nyelvű, hosszúságú, és tartalmú dokumentumot, az Eurocode szabványok figyelembevétele nélkül is. Ezen publikációk tömkelege segített egymáshoz illeszteni a széthullott mozaikdarabkákat, amely által kialakíthattunk egy integrált képet a szerkezet ellenőrzésének kézi folyamatáról.

Az Eurocode 3 szabvány szerinti procedúrát követve olyan akadályokba ütközhetünk, amely megkövetel számos tapasztalatra vagy mérnöki intuícióra alapozott döntéshozatalt. Ezek alapján a ködös, vagy az esetenkénti hiányos útmutatásból adódó számolási folyamat végeredményének helyessége kételkedésre adhat okot, adott esetben pedig zsákutcába is vezetheti a gyakorló mérnököt.

\section{Szakirodalmi hivatkozások}

[1] Nagy Zs.: Studiul soluțiilor constructive și performanțelor structurale ale halelor ușoare cu structura realizată din profile de oțel formate la rece, Editura Politehnica - Timișoara, Timișoara, 2006.

[2] EN 1993-1-1: Design of steel structures - Part 1-1: General rules and rules for bulidings, 2006.

[3] EN 1993-1-3: Design of steel structures - Part 1-3: General rules - Supplementary rules for coldformed members and sheeting, 2008.

[4] Iványi M.: Acélszerkezetek tervezése az Eurocode szerint. Budapest, 2007. 17.

[5] Papp F.: Szerkezetépítés II. Tervezési segédlet, Stabilitásvizsgálat, Győr, 2015. 2-6. 